Univerzitet u Beogradu
Poljoprivredni fakultet
Institut za poljoprivrednu tehniku
Naučni časopis
POLJOPRIVREDNA TEHNIKA
Godina XLIV
Broj 3, 2019.
Strane: $78-91$

UDK: 631.4

Originalni naučni rad Original scientific paper doi: 10.5937/PoljTeh19030780

\title{
EVALUATION OF THE CAUSES OF EROSION AND SOLUTION: CASE STUDY UMUOKORO LOWA, IHITTE/UBOMA LOCAL GOVERNMENT AREA, IMO STATE
}

\author{
Oluwaseun Ojedele $^{1 *}$, Anthony Eke ${ }^{1}$, Precious Ehiomogue ${ }^{1}$, Nkiru Ezejiofor ${ }^{2}$ \\ ${ }^{1}$ Michael Okpara University of Agriculture, Umudike, Nigeria \\ ${ }^{2}$ National Agricultural Extension Research and Liaison Service, \\ Ahmadu Bello University, Zaria, Nigeria
}

\begin{abstract}
Erosion is a condition in which the surface of the earth declines gradually due to wearing away by the action of water, wind and human activities. This research was carried out to determine the types of erosion occurring in this area and provide proper erosion management techniques that will help to control the erosions occurring in this area. Erosion control techniques are used to prevent and reduce soil erosion. Visual examination, interviews from residents and measurement of measurement of the erosion to know the cause, nature and type of erosion at the sites were carried out. Results of visual examination and interviews revealed that the erosion was caused by abandoned road construction and poor land management practices of the residents. Measurements from site A, D and G at the month of May which were $0.28,0.29$ and $0.29 \mathrm{~m}$ in depth respectively showed that they have already degenerated from splash to rill and is gradually forming gully, while site $\mathrm{B}$ and $\mathrm{C}$ at the month of May which were 1.53 and $2.34 \mathrm{~m}$ in depth respectively were still active gullies. Site F and G have already degenerated from rill to gully and will be worse if nothing is done on time. Implementation of the solutions recommended like regarding and tarring the roads, planting vegetative covers and proper sensitization of the villagers is necessary to improve and maintain the environment.
\end{abstract}

Keywords: Erosion, Earth, Human Activities, Gully, Solutions.

\footnotetext{
${ }^{*}$ Correspond Author. E-mail address: ojedelestephen@gmail.com
} 


\section{INTRODUCTION}

Soil is a dynamic natural body on the surface of the earth in which plants grow, it is composed of minerals and organic materials and living forms [1]. Soil is a key element to agriculture without it, we won't be able to grow plants, which are used as food for both humans and animals.

In general, farmers lose a large amount of the top soil each year which is estimated to about 24 billion tones to erosion in developing countries. Erosion rate per acre are twice as high as the standard partly because population pressure forces land to be more intensively farmed [2]. Soil erosion refers to the removal of soil materials from their original location and their subsequent transport to another location through the action of wind, water, ice, biotic processes, or human activities [3]. The level of soil destruction differs in different parts of the country, depending on the cause of the erosion $[4,5,6]$. Erosion leads to loss of land for agriculture, resulting to reduction in annual crop yield. Soil erosion may be induced naturally or artificially, meanwhile, the natural occurrence poses more environmental hazards [7]. According to [8, 9], erosion of the soil occurs in four major stages, which are; detachment by rain drop impact; transport by raindrop impact (splash erosion); detachment by the shearing forces of flowing water and transport in surface runoff (sheet erosion, rill and gully erosion). Gully erosion is the most destructive type of erosion, which is characterized with ephemeral flow, large channel which may reach or more than $0.3 \mathrm{~m}$ and $0.6 \mathrm{~m}$ in width and depth respectively [10]. Erosion is a serious problem for agricultural production as it has greatly affected agricultural productive lands. Reduction in yield of up to $50 \%$ has been documented on severely eroded soils in many parts of the world [11]. The crops grown in this areas have poor nutrients and provides poor nourishment to individuals that consumes them.

Excessive and accelerated erosion cause both "on site" and "off-site" problems, like decrease in agricultural productivity, sedimentation of water ways, eutrophication of water bodies, damage to roads and houses. Erosion must be kept to acceptable limits in accordance to [12]. However, Vegetation growth in regions with regular rainfall could be a preventive measure for erosion [13]. There are various materials used as preventive measures in controlling erosion. Some of the common materials are limestone, granite, vegetation, staked perforated plastic sheet, coconut fiber, straw, steel wire mesh cage. There are techniques similar to natural method of protecting the soil that is employed in preventing erosion. These include conservation practices which positively affect major erosion and sedimentation and thus, reduce sediment movement in one or more ways. These techniques include: absorbing rain drop impact energy, absorbing run off, slowing run-off scour forces, and prevention of soil massive movement [14]. Also, there are other methods that are used in erosion control, with some listed viz-a-viz, reforestation, riprap, gabions, buffer strip, sand fence, fiber rolls, erosion control blankets, and provision of water channels to divert water and eliminate flooding.

Erosion is a major problem experienced annually in Umuokoro Lowa village, Ihitte/Uboma local government area, Imo state. The adverse effect of erosion in this area has hindered development in the community. There are some techniques that have been applied in the community like the use of sand bags, which are not effective to tackle soil erosion. Therefore, there is need to investigate on the causes of erosion in the area and proffer adequate solution that can help Umuokoro Lowa village, in Ihitte/Uboma local government area of Imo State in restoring the affected sites in the community. 
To achieve this target, there was identification and evaluation of the various types of erosions that are predominant in the village, identification of the efficiency of the various types of erosion control measures that already exists, and proffered possible solutions with adequate preventive measures for the affected areas. Soil plays an important and integral role in our everyday life that supplies our foods, support our houses and highway and acts as building materials.

The research is targeted to solving a problem of erosion by investigating the causes, effects and proffer solutions to erosion based on the findings. This research work would be of importance and have benefits to the country by reducing the alarming rate of environmental dilapidation through soil loss. The research will help to create awareness on the types and causes of erosion and the dangers attached if it is not arrested on time. It will also provide information to prevent erosion occurrence by providing erosion control measures that would help to checkmate the menace in future.

\section{MATERIALS AND METHOD}

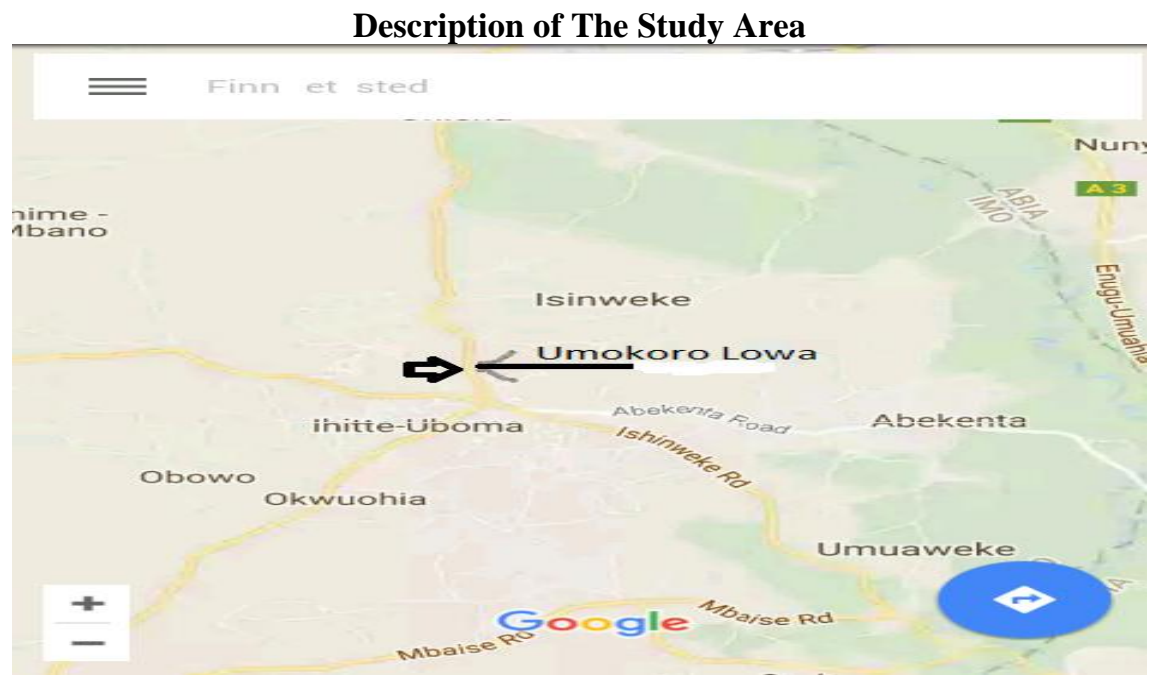

Figure 1: Umuokoro Lowa village, [15]

Umuokoro Lowa is a village in Okata community in Ihitte/Uboma Local Government Area of Imo state, Nigeria. It can be located on latitude $5^{\circ} 37^{\prime} 18^{\prime}$ ' $\mathrm{N}$ and longitude $7^{0} 21^{\prime} 54.9^{\prime}$ 'E. The climatic region is in the rain forest zone of Nigeria. The climate is characterized by two seasons, which are the rainy season and the dry season. The rainy season starts from April and end in September while the dry season starts from October and ends in March. Although, there are some times when there may be change in atmospheric condition, like this year that the rainy season started early at February. The village has a sloppy landscape which makes it prone to erosion. 


\section{Materials and Their Usefulness}

The materials used in this research work are (i) Field record book (ii) Pen (iii) Surveyor's Tape (iv) Carpenters Tape (v) Camera. Field Record Book was used to record the readings from the measurement of the erosion areas. Pen was used in writing down the readings. Surveyor's tape was used in taking measurements which are the length, width, and depth of the eroded areas. Carpenters tape was used in taking short distance measurements of the eroded areas. Camera was used in the reconnaissance stage to take pictures of the locations.

\section{Methods}

This research work was carried out in two stages: (1) The reconnaissance stage/survey (2) investigation of the erosion in the area.

\section{Reconnaissance Stage/Survey}

The field inspection was carried out randomly to locate the erosion areas by taking necessary photographs of the affected sites in Umuokoro Lowa.

\section{Investigation of the Erosion Area}

The survey of the erosion areas was carried out through visual examination and measurement of the erosion characteristics which are length, width and depth to ascertain the nature and types of erosion occurring in the area. The work was done using $30 \mathrm{~m}$ surveyors tape to take long distance measurements and $12 \mathrm{~m}$ carpenters tape in taking short distance measurements. The readings were tabulated and the erosion types identified from the size of their depth according to readings from literatures. They were: Length (It was measured to determine the distance of the erosion); Width (It was measured to determine the wideness of the erosion); Depth (It was measured to determine how deep the erosion have gone and also to know the type of erosion occurring in the place); Nature of the erosion (This was to know the state of the erosion whether still active or not). In terms of Classification, the erosion type was classified based on the depth of incision as cropped from standard literature. Sheet: $0 \mathrm{~cm}-4 \mathrm{~cm}$; Rill: 5cm ---30cm; Gully: 40cm and above. [16, 17]. 


\section{RESULTS AND DISCUSSION}

\section{Description of Site A}

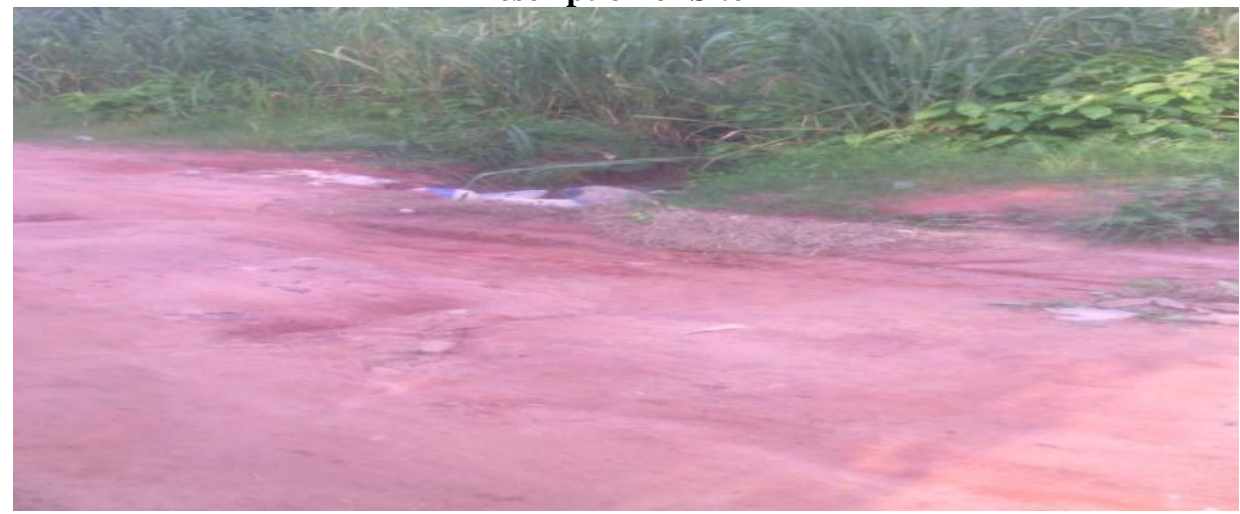

Plate 1: Erosion at site A

Table 1: Observation at site A

\begin{tabular}{|l|l|l|l|l|l|l|l|}
\hline Month & \multicolumn{2}{|c|}{ Length $(\mathrm{m})$} & \multicolumn{2}{|c|}{ Width $(\mathrm{m})$} & \multicolumn{2}{|c|}{ Depth $(\mathrm{m})$} & Nature \\
\hline & $X$ & $Y$ & $X$ & $Y$ & $X$ & $Y$ & \\
\hline March & 9.3 & 9.8 & 0.99 & 1.14 & 0.14 & 0.17 & Rill \\
\hline April & 9.8 & 10.2 & 1.14 & 1.24 & 0.17 & 0.23 & Rill \\
\hline May & 10.4 & 11.1 & 1.27 & 1.35 & 0.23 & 0.28 & Rill \\
\hline
\end{tabular}

$X=$ dimension before rainfall, $Y=$ dimension after rainfall

\section{Causes and Evaluation of Erosion at Site A}

The road was only graded and was not tarred, a graded road is prone to erosion because it is similar to a bare ground that does not have cover it should be tarred hence, the road graduated from splash to sheet then to rill. If care is not taken it will graduate to gully erosion. From the report gotten from the residents, it was observed that this site was not too bad until the time it was graded for construction.

\section{Proffered Solution to Site A}

The road should be re-awarded for finishing work and it should be completed by grading the road and ensure that is tarred and it must be reconstructed with side drains both at the left and right sides of the road. The work of the side drains is to transport water during rainfall from the road to the bushes. In addition mitre drain should be constructed with the side drain because sometimes the rainfall intensity and long duration of rain will make the side drains to be overflowed. Therefore, mitre drain is constructed along the side drain at 20 to 25 meter range. The work of the mitre drain is to divert excess runoff into the bush and prevent the road from been damaged by flood. 


\section{Description of Site B}

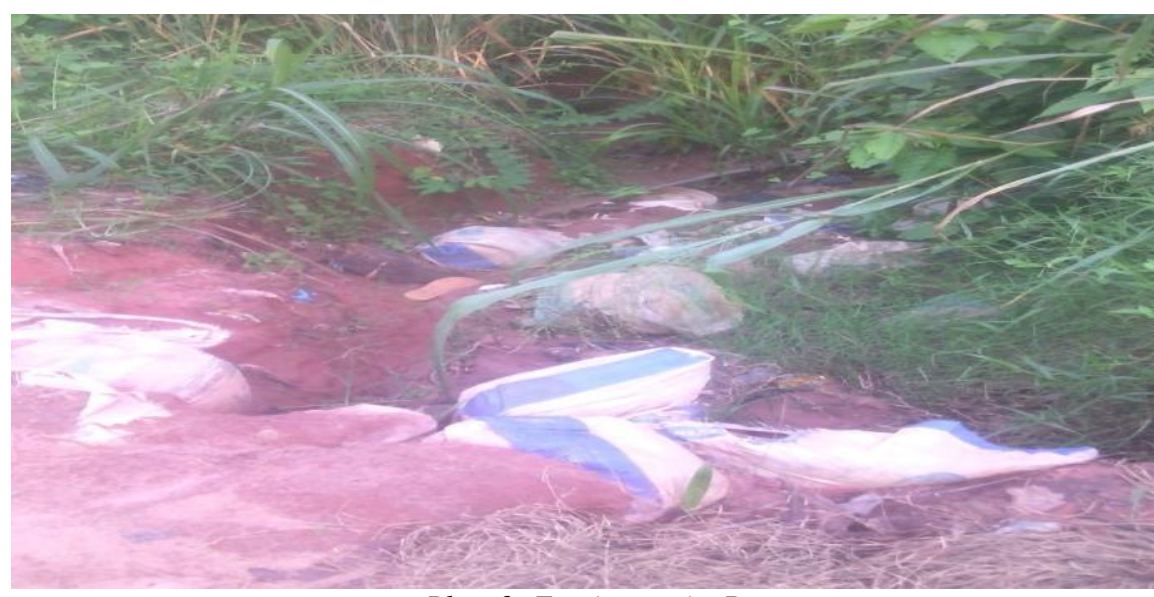

Plate 2: Erosion at site B

Table 2: Observation at site B

\begin{tabular}{|c|c|c|c|c|c|c|c|}
\hline \multirow[t]{2}{*}{ Month } & \multicolumn{2}{|c|}{ Length $(\mathrm{m})$} & \multicolumn{2}{|c|}{ Width $(m)$} & \multicolumn{2}{|c|}{ Depth $(m)$} & \multirow[t]{2}{*}{ Nature } \\
\hline & $X$ & $Y$ & $X$ & $Y$ & $X$ & $Y$ & \\
\hline March & 13.37 & 13.45 & 0.98 & 1.12 & 0.94 & 0.99 & Gully \\
\hline April & 13.45 & 13.56 & 1.12 & 1.20 & 0.99 & 1.3 & Gully \\
\hline May & 14.06 & 15.00 & 1.26 & 1.32 & 1.39 & 1.53 & Gully \\
\hline
\end{tabular}

$X=$ dimension before rainfall, $Y=$ dimension after rainfall

\section{Causes and Evaluation of Erosion at Site B}

From plate 2, it can be observed that the rate of runoff in this area is very high as it has already carried away the sand bags used in checking it. The water coming into the gully from different runoff sources has high erosive effect on the soil, because the interceptor ditches used in intercepting them where removed in the cause of abandoned road construction. From residents' point of view, it was observed that erosion in this site was aggravated due to human activities like soil excavation and improper refuse disposal thereby blocking the runoff channel. It was also observed that the removal of the interception channels also led to the increase in runoff passing through the area. 


\section{Proffered Solution to Site B}

The runoff sources should be traced first and vegetative covers like grasses should be planted within the runoff sources to reduce the velocity of water flowing into the gully site. It can also be controlled by building a silt fence with gravel bags which will trap sediments that will fill the gully and allow easy passage of water through the pores of the bag. Reconstruction of interceptor ditches should be properly done so that runoff will be intercepted and prevented from coming down to this site.

\section{Description of Site C}

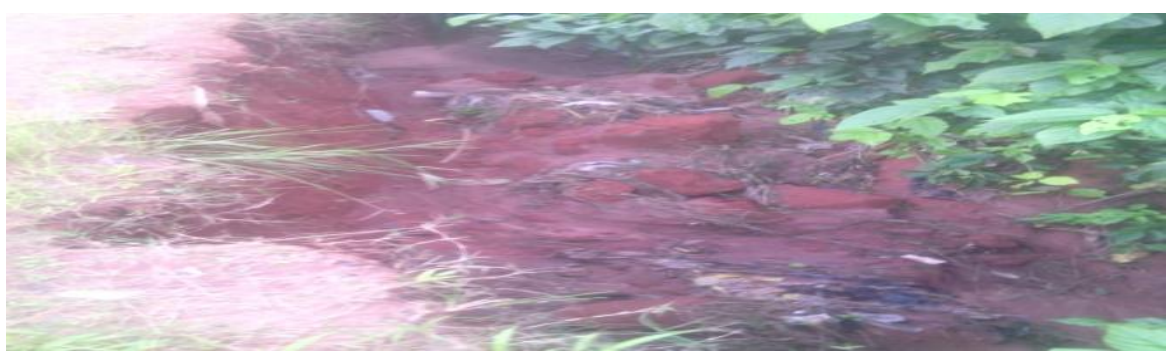

Plate 3: Erosion at site C

Table3: Observation at site $C$

\begin{tabular}{|c|c|c|c|c|c|c|c|}
\hline Month & \multicolumn{2}{|c|}{ Length $(\mathrm{m})$} & \multicolumn{2}{|c|}{ Width $(\mathrm{m})$} & \multicolumn{2}{|c|}{ Depth (m) } & Nature $(m)$ \\
\hline & $X$ & $Y$ & $X$ & $Y$ & $X$ & $Y$ & \\
\hline March & 8.6 & 9.0 & 3.0 & 3.29 & 1.7 & 2.0 & Gully \\
\hline April & 9.0 & 9.4 & 3.29 & 3.4 & 2.0 & 2.17 & Gully \\
\hline May & 9.46 & 10.7 & 3.45 & 4.0 & 2.26 & 2.34 & Gully \\
\hline
\end{tabular}

$X=$ dimension before rainfall., $Y=$ dimension after rainfall

\section{Causes and Evaluation of Erosion at Site C}

From the plate 3 and response gotten the residents, it was observed that the gully occurring in this area is still very active. This site is a natural runoff channel but has been destroyed and exposed to erosion due to constant sand excavation that goes on there at the end of every rainfall. This has led to the softening of the soil allowing it to be easily washed off by runoff water.

\section{Proffered Solution to Site C}

The type of erosion occurring in this area is gully erosion. This type of erosion can be controlled firstly by tracing the runoff sources and reducing the speed through planting vegetative covers which will help reduce the velocity of the runoff that is passing through this channel. It can also be controlled by the use of Gabions, the gabions are made of a porous structure that is made of heavy duty wire netting that is filled with stones which will make for easy passage of water and allow sediment concentration that will help the area to recover its lost soil. Terraces can also help in controlling the amount of runoff that goes into the by diverting the runoff into other channels. 
Finally, laws should also be enacted to control the human activities that contribute to the erosion problem.

\section{Description of Site D}

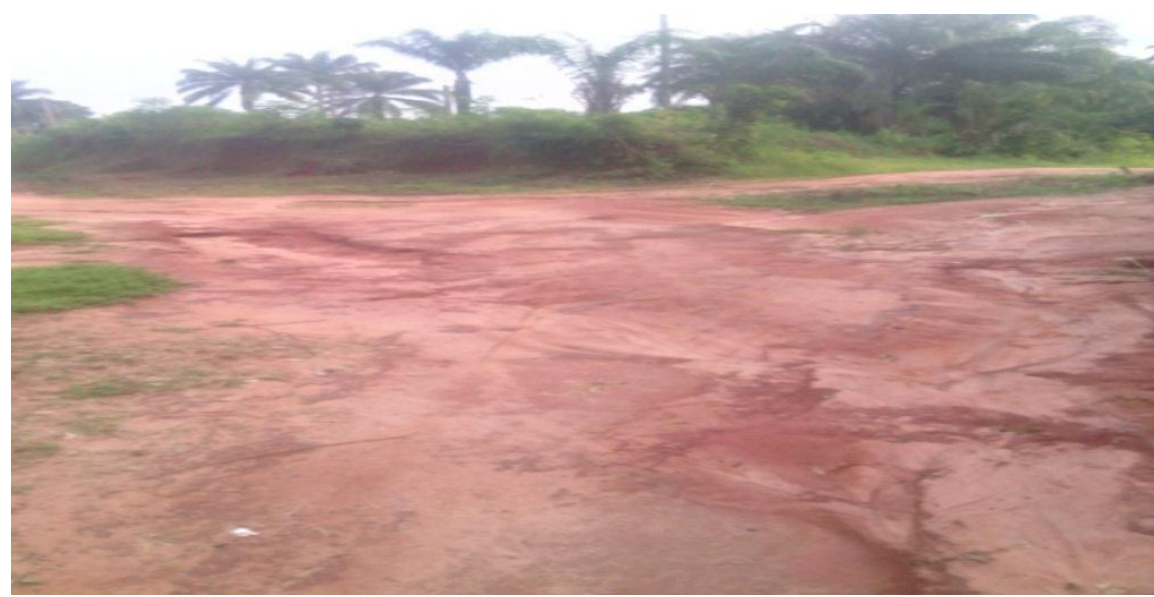

Plate 4: Erosion at site D

Table 4: Observation at site $D$

\begin{tabular}{|c|c|c|c|c|c|c|c|}
\hline \multirow[t]{2}{*}{ Month } & \multicolumn{2}{|c|}{ Length (m) } & \multicolumn{2}{|c|}{ Width $(m)$} & \multicolumn{2}{|c|}{ Depth (m) } & \multirow[t]{2}{*}{ Nature ( $m$} \\
\hline & $X$ & $Y$ & $X$ & $Y$ & $X$ & $Y$ & \\
\hline March & 29.65 & 29,83 & 0.86 & 0.92 & 0.14 & 0.18 & Rill \\
\hline April & 29.83 & 30.9 & 0.92 & 1.24 & 0.18 & 0.22 & Rill \\
\hline May & 32.32 & 34.0 & 1.28 & 1.36 & 0.24 & 0.29 & Rill \\
\hline
\end{tabular}

$X=$ dimension before rainfall. $Y=$ dimension after rainfall

\section{Causes and Evaluation of Erosion at Site D}

This area is sloppy in nature and is barred of vegetative covers and drainage passage, this makes it easy for raindrops and erosive water to move freely on the land surface with high velocity causing the soil to be detached and carried away. From residents response there was vegetative covers in this area before the road was graded.

\section{Proffered Solution to Site D}

The type of erosion occurring in this area is rill. This can be controlled by the following ways: Drainage ways should be constructed at both sides of the road, the runoff sources should be traced and the runoff water diverted into the constructed drainages by creating channels that will help carry the runoff water into the drainages or by laying underground pipes that will carry the water. This will reduce the amount of water that will flow down the slope without having effect on the soil. Secondly, vegetative covers should be planted; this will help absorb the impact of raindrops and runoff velocity on the soil surface by increasing infiltration rate. 
Also, a semi-permeable synthetic ground cover(fabric) can be laid on the slope add stability, it will slow the water flow and allow it to be absorbed by the soil, as well as keeping the water from washing the soil away. Finally, the road should be graded and asphalted with drainage structures or ditches constructed at both sides of the road this will eradicate the erosion at this site for a long period of time.

\section{Description of Site $E$}

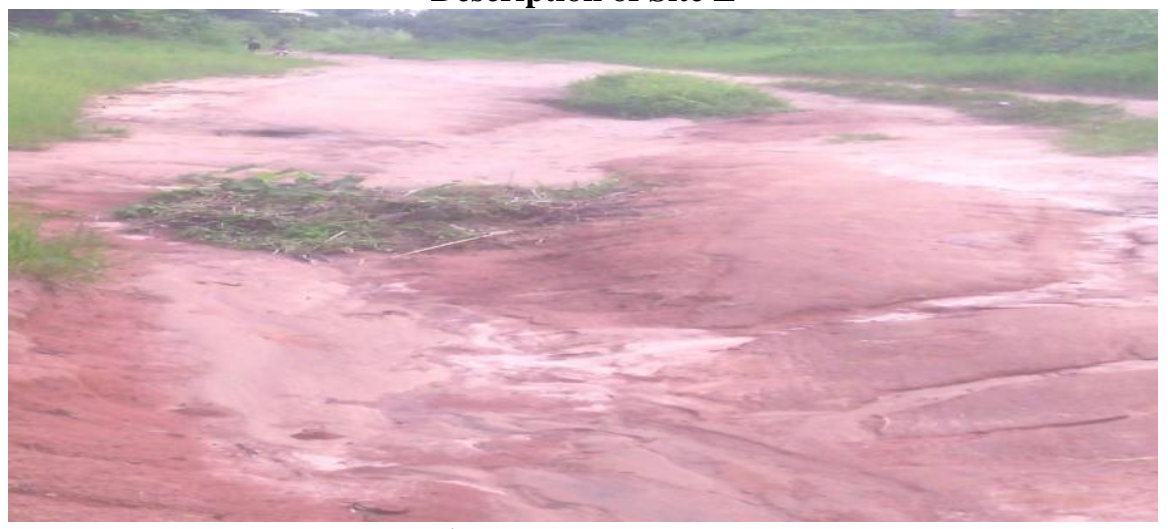

Plate 5: Erosion at site $E$

Table 5: Observation at site $E$

\begin{tabular}{|c|c|c|c|c|c|c|c|}
\hline \multirow[t]{2}{*}{ Month } & \multicolumn{2}{|c|}{ Length $(\mathrm{m})$} & \multicolumn{2}{|c|}{ Width (m) } & \multicolumn{2}{|c|}{ Depth $(m)$} & \multirow{2}{*}{ Nature $(m)$} \\
\hline & $X$ & $Y$ & $X$ & $Y$ & $X$ & $Y$ & \\
\hline March & 29.45 & 30.9 & 1.35 & 1.43 & 0.21 & 0.27 & Rill \\
\hline April & 30.9 & 32.0 & 1.35 & 1.43 & 0.27 & 0.33 & Gully \\
\hline May & 33.0 & 34.0 & 1.48 & 2.02 & 0.37 & 0.43 & Gully \\
\hline
\end{tabular}

$X=$ dimension before rainfall, $Y=$ dimension after rainfall

\section{Causes and Evaluation of Erosion At Site E}

From the plate 5 it can be observed that the rate of runoff flow is too high in this area and the land is barred of vegetative covers that will reduce the speed of the runoff thereby causing it break and carry away the soil particles easily. Responses from the residents showed that the removal of drainage channels that were in this area due to construction led to the occurrence of erosion.

\section{Proffered Solution to Site E}

The type of erosion occurring in this site is gully. To get this area under control, the sources of erosion should be tackled first. These sources can be tackled by reducing the runoff speed so that the rate of erosion occurring at site $\mathrm{E}$ will be reduced. The runoff sources can be reduced by planting grasses and trees that can thrive in the environment. Channels should be created by the sides of the road to divert the excess runoff that the adjacent side of the road. The eroded portions should be mulched before grading or filled with stones to enable it trap sediments and reduce the rate of scouring and soil loss. 
If the road can be graded and asphalted with drainage channels at both sides of the road, it will be the best solution in solving the erosion menace at this site.

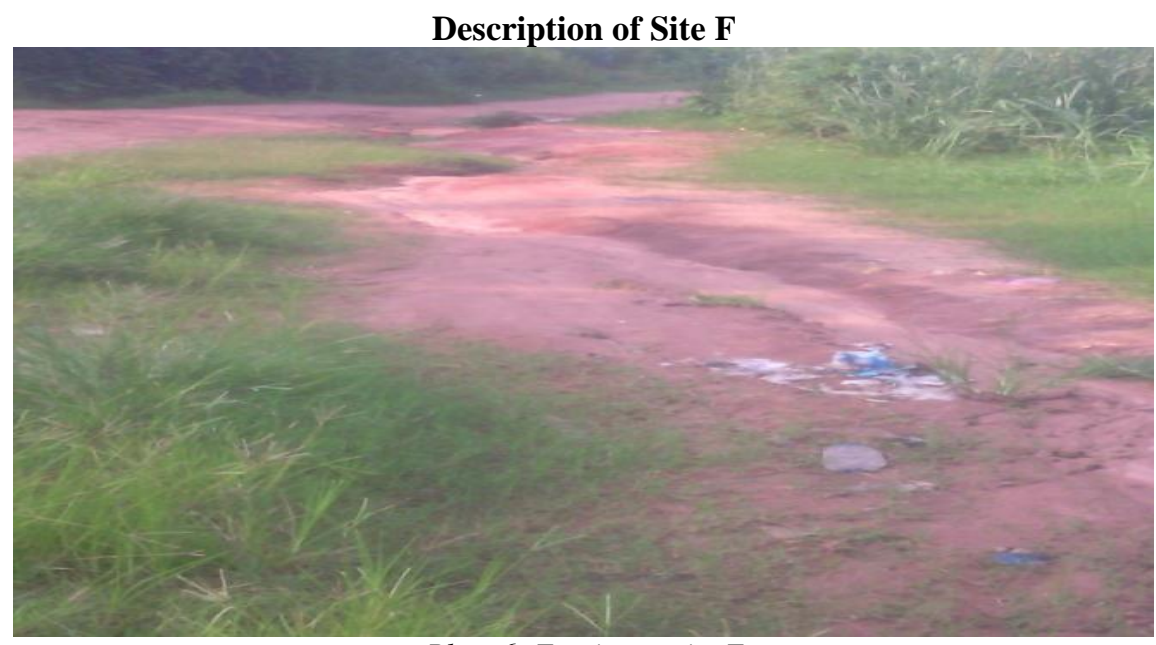

Plate 6: Erosion at site F

Table 6: Observation at site F

\begin{tabular}{|c|c|c|c|c|c|c|c|}
\hline \multirow[t]{2}{*}{ Month } & \multicolumn{2}{|c|}{ Length $(\mathrm{m})$} & \multicolumn{2}{|c|}{ Width $(\mathrm{m})$} & \multicolumn{2}{|c|}{ Depth $(m)$} & \multirow[t]{2}{*}{ Nature $(m)$} \\
\hline & $X$ & $Y$ & $X$ & $Y$ & $X$ & $Y$ & \\
\hline March & 27.56 & 28.70 & 1.27 & 1.38 & 0.22 & 0.26 & Rill \\
\hline April & 28.70 & 29.82 & 1.38 & 1.43 & 0.26 & 0.29 & Rill \\
\hline May & 31.64 & 33.56 & 1.69 & 1.93 & 0.32 & 0.34 & Gully \\
\hline
\end{tabular}

$X=$ dimension before rainfall, $Y=$ dimension after rainfall

\section{Causes and Evaluation of Erosion at Site F}

The land management practice in this area is very poor as the drainage channels has been covered with sediments and bushes there by, causing runoff water to flow through the road and cause erosion since the soil in the area is no longer compactable to accommodate the flow without been washed away.

\section{Proffered Solution to Site F}

The type of erosion occurring in this area is gully. This type of erosion can be reduced by first clearing the drainage channels so that runoff water can flow freely without been obstructed. Terraces can also be built to divert excess runoff away from the road. 


\section{Description of Site G}

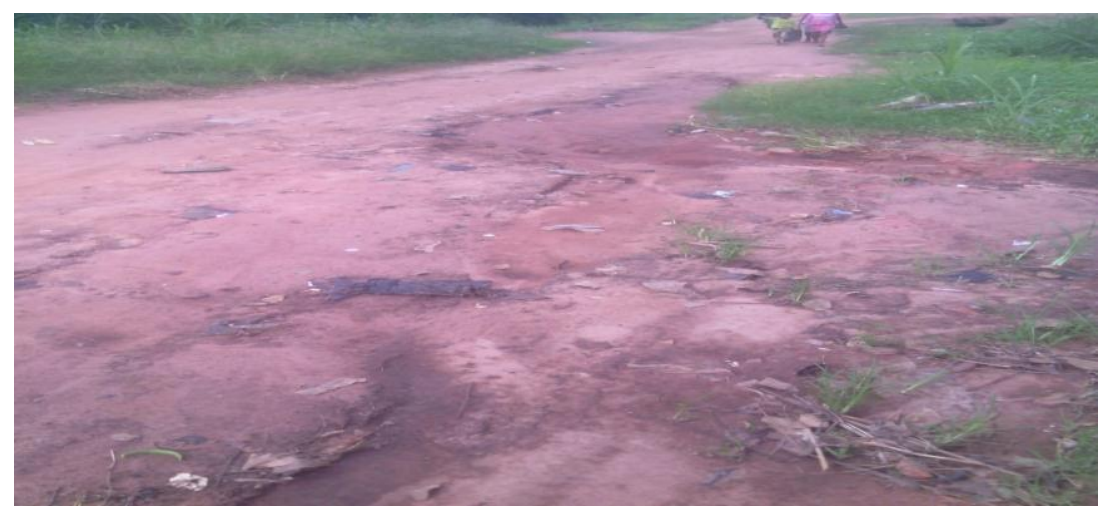

Plate 7: Erosion at site G

Table 7: Observation at site $G$

\begin{tabular}{|c|c|c|c|c|c|c|c|}
\hline Month & \multicolumn{2}{|c|}{ Length $(\mathrm{m})$} & \multicolumn{3}{c|}{ Width $(\mathrm{m})$} & \multicolumn{3}{c|}{ Depth $(\mathrm{m})$} & Nature $(\mathrm{m})$ \\
\hline & $X$ & $Y$ & $X$ & $Y$ & $X$ & $Y$ & \\
\hline March & 26.78 & 27.02 & 1.35 & 1.38 & 0.16 & 0.23 & Rill \\
\hline April & 27.02 & 27.54 & 1.38 & 1.45 & 0.23 & 0.26 & Rill \\
\hline May & 28.03 & 28.67 & 1.50 & 1.86 & 0.26 & 0.29 & Rill \\
\hline
\end{tabular}

\section{Causes and Evaluation Of Erosion at Site F}

The rate of rainfall in this area is very high and the area lacks drainage control channels which make it easy for erosive water to be passing through the road causing the soils to be easily detached and carried away. The resident in this area observed that the erosion started occurring due to the removal of drainage channels and abandonment after grading the area for construction.

\section{Proffered Solution to Site F}

Drainage channels should be created at both sides of the road, the road should also be graded and vegetative covers that thrive in the area should be planted too to help reduce raindrop impact and runoff speed.

\section{CONCLUSION}

Examinations of the various types of erosion occurring in Umuokoro Lowa, Ihitte/Uboma L.G.A Imo State had been investigated, and solutions that can help manage the menace had been proffered. It was discovered that Site A, D and G have been eroded to a depth of 28,29 and $29 \mathrm{~cm}$ respectively from splash to rill and is gradually forming gully, while site B and C at the month of May which were 1.53 and $2.34 \mathrm{~m}$ in depth respectively were still active gullies. 
Site $\mathrm{F}$ and $\mathrm{G}$ have already degenerated from rill to gully and will be worse if nothing is done on time. It was concluded that the rate at which erosion is occurring in the area is at high level and requires quick intervention. It was also observed that the erosions were due to construction and poor maintenance culture by the inhabitants.

In other to prevent impending disaster trying to occur in this area, it is recommended that the solutions and techniques proffered should be put in place without further delay. Government and other agencies charged with the responsibility of protecting the environment should take proactive measures in educating the populace on the adverse effects associated with this menace, proper drainage management system should be in place when designing plans for road construction. Finally, the community should imbibe the culture of proper waste disposal system and avoid practices that will lead to water way blockage.

\section{BIBLIOGRAPHY}

[1] Brady, N. C, Raymond R. Weil. 2016. The Nature and Property of Soils.15 Ed. Pearson Global Edition, Inc, New York, N.Y.

[2] Dahaan, R. 2006. International Erosion Control on Potato Land in Atlantic Canada.Atlantic Committee on Agricultural Engineering.

[3] Rainey S. J.2010. Soil Erosion B.Warf (Ed.), Encyclopedia of Geography. Thousan Oaks, A Sage Publications. Retrieved from https://search.credoreference.com/content/sagegeography/soil-erosiion/0

[4] Onwueme, I.C and Asiabaka, C.C.1992. Erosion as an Interactive Force in the Human Environment. Erosion Research Centre, FUTO

[5] Idah, P.A., Mustapha, H.I., Musa, J.J., Dike, J.2008. Determination of Erodibility Indices of Soils in Owerri West Local Government Area of Imo State, Nigeria. AU. J.T 12 (2) 130 - 133.

[6] Onu, N.N. 2011. Training in Geophysics: The Challenges of oil exploration, Gully Erosion and Water resources Development. 18th Inaugural Lecture of the Federal University of Technology, FUTO, Owerri.

[7] Albert, A. A., Samson, A. A., Peter, O. O. and Olufunmilayo, A. O. 2006. An Assessment of the Socio Economic Impacts of Soil Erosion in South-Eastern Nigeria, Shaping the Change, XXIII FIG Con. Munich, Germany, pp. 12, 2006.

[8] Abdulfatai I. A., Okunlola I.A., Akande W.G., Momoh L. O., and Ibrahim K. O., "Review of Gully Erosion in Nigeria: Causes, Impacts and Possible Solutions." Journal of Geosciences and Geomatics, vol. 2, no. 3 (2014): 125129. doi: 10.12691/jgg-2-3-8.

[9] Foster, G.R. and Meyer, L.A. 2010. Mathematical Stimulation of Upland Erosion by Fundamental Erosion Mechanics; Present and Prospective Technique for Predicting Sediment Yields and Sources. Proc.Sediment Yield Workshop, USDA Sediment Lab; Nov. 28-30 2001, 190-204. 
[10] El-Swaify, S. A. 1990. Research needs and applications to reduce erosion and sedimentation in the tropics, IAH-AISH Publication, No. 192, 3-13.

[11] Rinehart, H. and Winston. 2004. The Winston Canadian Dictionary for School. Holt,Rinehart and Winston of Canada, Ltd. Toronto.

[12] FAO. 2010. Soil Erosion by Water, FAO Publication Italy.

[13] Lal, R. 2006. Soil Conservation: Preventive and Control Measure in Soil Conservation Problems and Prospects. Ed. R.P.C, Morgan John Wiley and Sons.Chichester . pp.180.

[14] Meyer, L. D. 2011. Modeling Conservation Practices; in Soil Conservation Problems and Prospect. Ed R.P.C Morgan. J.Wiley and Sons, Chichester. Pg35.

[15] https://google.no/maps/@5.62182,7.3625,12z

[16] Onwualu, A. P., Akubuo, C. O. and Ahaneku, I. E.2006. Fundamentals of Engineering for Agricultural; Immaculate Publication Limited, Enugu, ISBN 978-036-133-2

[17] https://agrihelper.blogspot.co.ke/2016/06/types-of-erosion-splashsheetrill-and$\underline{\mathrm{html}} \mathrm{m}=1$

\section{EVALUACIJA UZROKA EROZIJE I REŠENJA: STUDIJA SLUČAJA UMUOKORO LOWA, IHITTE/UBOMA LOKALNA UPRAVA, IMO DRŽAVA, NIGERIJA.}

\section{Oluwaseun Ojedele ${ }^{1}$, Anthony Eke ${ }^{1}$, Precious Ehiomogue ${ }^{1}$, Nkiru Ezejiofor ${ }^{2}$}

${ }^{1}$ Michael Okpara University of Agriculture, Umudike, Nigeria

${ }^{2}$ National Agricultural Extension Research and Liaison Service, Ahmadu Bello University, Zaria, Nigeria

Sažetak: Erozija je stanje u kojem se površina Zemlje postepeno smanjuje zbog odnošenja čestica sa vodom, vetrom ili ljudskim aktivnostima.

Ovo istraživanje je sprovedeno kako bi se utvrdile vrste erozije koje se dešavaju u ovoj oblasti i obezbedile odgovarajuće tehnike upravljanja intenzitetom erozije, koje će pomoći u kontroli procesa erozija koje se dešavaju u ovoj oblasti.

Tehnike kontrole erozije koriste se za sprečavanje i smanjenje erozije zemljišta. Izvršeno je vizuelno ispitivanje, intervjuisanje stanovnika i merenje erozije, da bi se znali uzrok, priroda i vrsta erozije na određenim lokalitetima.

Rezultati vizuelnog pregleda i intervjua pokazali su da je erozija uzrokovana napuštanjem izgradnje/održavanja puteva i lošom praksom upravljanja i upotrebe zemljišta od strane lokalnih stanovnika. Merenja sa lokaliteta A, D i G u mesecu maju, koja su bila 0,28, 0,29 i 0,29 m dubine, pokazala su da već postoje degradacije od padavina i neadekvatne obrade koje postepeno formiraju jarak.

Lokacije B i C u mesecu maju, mereno na 1.53 i $2.34 \mathrm{~m}$ dubine, pokazuju još aktivniju pojavu jaraka (erozije) na površini. Lokacije F i G su degradirane obradom do pojave jaruga i biće intenzivnije ako se ništa ne uradi na vreme. 
Implementacija rešenja koja se preporučuju, kao što je ravnanje i tanjiranje površine puteva, sadnja vegetacionih pokrivača i pravilna informacija lokalnih stanovnika korisnika ovih površina, neophodna je za poboljšanje i održavanje životne sredine.

Ključne reči: Erozija, Zemlja, ljudske aktivnosti, jaruga, rešenja

Prijavljen:

Submitted:

15.05.2019

Ispravljen:

Revised:

12.06.2019.

Prihvaćen:

Accepted:

30.08 .2019 